\title{
Bacterial epibionts of Daphnia: a potential route for the transfer of dissolved organic carbon in freshwater food webs
}

\author{
Ester M Eckert and Jakob Pernthaler \\ Limnological Station, Institute of Plant Biology, University of Zurich, Kilchberg, Switzerland
}

\begin{abstract}
The identification of interacting species and elucidation of their mode of interaction may be crucial to understand ecosystem-level processes. We analysed the activity and identity of bacterial epibionts in cultures of Daphnia galeata and of natural daphnid populations. Epibiotic bacteria incorporated considerable amounts of dissolved organic carbon (DOC), as estimated via uptake of tritiated leucine: three times more tracer was consumed by microbes on a single Daphnia than in $1 \mathrm{ml}$ of lake water. However, there was virtually no incorporation if daphnids were anaesthetised, suggesting that their filtration activity was essential for this process. Microbial DOC uptake could predominantly be assigned to microbes that were located on the filter combs of daphnids, where the passage of water would ensure a continuously high DOC supply. Most of these bacteria were Betaproteobacteria from the genus Limnohabitans. Specifically, we identified a monophyletic cluster harbouring Limnohabitans planktonicus that encompassed sequence types from $D$. galeata cultures, from the gut of Daphnia magna and from daphnids of Lake Zurich. Our results suggest that the epibiotic growth of bacteria related to Limnohabitans on Daphnia spp. may be a widespread and rather common phenomenon. Moreover, most of the observed DOC flux to Daphnia in fact does not seem to be associated with the crustacean biomass itself but with its epibiotic microflora. The unexplored physical association of daphnids with heterotrophic bacteria may have considerable implications for our understanding of carbon transfer in freshwater food webs, that is, a trophic 'shortcut' between microbial DOC uptake and predation by fish.
\end{abstract}

The ISME Journal (2014) 8, 1808-1819; doi:10.1038/ismej.2014.39; published online 3 April 2014

Subject Category: Microbe-microbe and microbe-host interactions

Keywords: Daphnia; epibionts; symbiosis; fresh water; food webs; dissolved organic carbon

\section{Introduction}

In order to accurately estimate element fluxes or predict ecosystem responses, it is essential to understand food web architecture (Bascompte, 2010). Unexplored trophic links may considerably alter food web structure, and can, once investigated, substantially change our understanding of ecosystem carbon metabolism (Corno et al., 2012; Kuwae et al., 2012). Therefore, interacting species and their mode of interaction need to be identified for more accurate assumptions about ecosystem functionality and stability (Thébault and Fontaine, 2010; Mougi and Kondoh, 2012).

The lack of information about the physical interactions between heterotrophic bacteria and zooplankton, such as the crustacean genus Daphnia, may neglect an important aspect of freshwater food

Correspondence: J Pernthaler, Limnological Station, Institute of Plant Biology, University of Zurich, Seestrasse 187, 8802 Kilchberg, Switzerland.

E-mail: pernthaler@limnol.uzh.ch

Received 26 September 2013; revised 6 February 2014; accepted 12 February 2014; published online 3 April 2014 webs (Tang et al., 2010). Indeed, little is known about the microbial communities associated with healthy Daphnia, as opposed to the plethora of research about the respective roles of either bacterioor zooplankton within aquatic food webs, or about microbial parasites of Daphnia (see, for example, Ebert, 2008; Newton et al., 2011; Miner et al., 2012). Recent studies, however, point to other systemrelevant associations between bacteria and Daphnia, for example, the transfer of microbes from lower to higher water layers via attachment-detachment processes (Grossart et al., 2010). The gut microflora of Daphnia magna was reported to be dominated by members of the genus Limnohabitans (Freese and Schink, 2011), that is, by common inhabitants of the pelagic zone of freshwater epilimnia that typically co-occur with phytoplankton (Šimek et al., 2005, 2011). High bacterial diversity, including phylotypes related to Limnohabitans, was also found when analysing prokaryotic sequences from metagenomic data of Daphnia spp. (Qi et al., 2009).

Whereas algae are generally regarded as the main food for daphnids, heterotrophic bacteria are considered less important (see, for example 
Peterson et al., 1978; Nagata and Okamoto, 1988; Martin-Creuzburg et al., 2011). However, some bacteria, notably filamentous morphotypes, are also consumed by Daphnia sp. that, in turn, may directly affect bacterial community structure at least during particular seasons (Langenheder and Jürgens, 2001; Pernthaler et al., 2004; Taipale et al., 2008). In addition, it is conceivable that the associations of zooplankton with heterotrophic bacteria may also have substantial implications for biogeochemical processes such as the transfer of carbon through the food web: although daphnids feed on organic carbon from the particulate fraction (Cole et al., 2006), the attached bacteria would likely consume dissolved organic carbon (DOC). Apart from a single more recent report (Speas and Duffy, 1998), uptake of DOC by Daphnia (or by their epibionts) has been addressed by studies dating from the beginning of the last century (see, for example, Kerb, 1911; Krogh, 1930). This largely unexplored trophic link might, however, be of great relevance for lake carbon cycling; for example, in the context of the much debated question of to what extent internal primary production or terrestrial carbon sources support freshwater ecosystems (see, for example, Grey et al., 2001; Pace et al., 2004; Brett et al., 2009). In such studies, the biomass of homogenised daphnids is proportionally assigned to allochthonous or autochthonous sources-by analysis of the isotopic ratios of carbon atoms-in order to model the fluxes of organic carbon through the food web. The zooplankton epibionts are considered as part of the Daphnia biomass; however, their specific metabolic abilities (that is, consumption of DOC) might considerably affect the interpretation of such assessments. Moreover, epibionts will be consumed by fish together with their host and might, thus, form a shortcut through the food web due to the transfers of organic matter, directly deriving from DOC, to fish.

We studied the uptake of dissolved leucine by Daphnia galeata or their epibionts to gain first insight into the importance of this trophic link, and we compared it with their ingestion of leucineincorporating planktonic microbes. Furthermore, we localised and identified a prominent genus of microbial epibionts responsible for this uptake on cultured D. galeata as well as on daphnids from mixed natural populations in a lake (Lake Zurich, Switzerland). Using leucine and $N$-acetyl-D-glucosamine (NAG) as model substrates, we then assessed the metabolic activity of Daphnia epibionts in Lake Zurich.

\section{Materials and methods}

Sampling and sample preparation

Lake Zurich was sampled weekly at $\sim 1000 \mathrm{~h}$ between 26 April and 24 May 2012 (coordinates $\left.47^{\circ} 31^{\prime} \mathrm{N}, 8^{\circ} 58^{\prime} \mathrm{E}\right)$. Chlorophyll $a$ and temperature were measured using a multiple-wavelength probe
(TS-16-12 fluoroprobe, bbe Moldaenke GmbH, Kronshagen, Germany) and a multi-parameter probe (6600 multi-parameter, water quality monitoring, YSI Incorp., Yellow Springs, OH, USA), respectively. The sample taken on 26 April was from the depth of maximum Chlorophyll $a(8 \mathrm{~m})$, whereas later samples were collected from $5 \mathrm{~m}$ depth because of the onset of the clear water phase (Figure 5). Zooplankton was collected using a Ruttner sampler, concentrated with a $40 \mu \mathrm{m}$ net from a volume of $5 \mathrm{l}$ and directly fixed with formaldehyde (final concentration, $4 \%$ ) for determination of abundances. Live daphnids were collected using the same device and transported to the laboratory in a clean jar. A third set of daphnids were immediately anaesthetised with carbon dioxide-enriched water for later experiments. The daphnids were kept in a laboratory incubator at in situ temperature for a maximum of $3 \mathrm{~h}$ before the experiments.

Next, $50 \mathrm{ml}$ of lake water was fixed with formaldehyde (final concentration, 1\%) for the analysis of total bacterial abundances and the proportions bacteria affiliated with the Beta-Proteobacteria genus Limnohabitans. Subsamples of $4 \mathrm{ml}$ were filtered onto white polycarbonate membrane filters (type GTTP, $45 \mathrm{~mm}$ diameter, $0.2 \mathrm{~mm}$ pore size; Millipore, Billerica, MA, USA) for the counting of Limnohabitans-related bacteria. The remaining sample was stored at $4{ }^{\circ} \mathrm{C}$ for flow cytometric determination of total cell numbers.

\section{Tracer experiments}

In experiment I (Figure 1), D. galeata females were kept in sterile $(0.2 \mu \mathrm{m}$ prefiltered and autoclaved) lake water (sLW) and fed with Scenedesmus subspicatus approximately every second day. Adult individuals were washed three times with sLW, and 6 sets of 4 individuals were transferred to $50 \mathrm{ml}$ Erlenmeyer flasks containing $10 \mathrm{ml}$ of sLW. Twelve additional individuals were anaesthetised in commercial carbon dioxide-enriched water, washed twice in sLW and 3 sets of 4 individuals were placed in $50 \mathrm{ml}$ Erlenmeyer flasks containing $10 \mathrm{ml}$ of sLW. Daphnids were acclimatised for $1 \mathrm{~h}$ in the dark at $20{ }^{\circ} \mathrm{C}$ before tracer addition.

Nine sets of $30 \mu \mathrm{m}$ prefiltered lake water $(10 \mathrm{ml}$ each) were incubated for $1 \mathrm{~h}$ with $10 \mathrm{~nm}$ of tritiumlabelled leucine (specific activity: $120 \mathrm{Ci} \mathrm{mmol}^{-1}$ ) or NAG (specific activity: $60 \mathrm{Ci} \mathrm{mmol}^{-1}$, American Radiolabeled Chemicals, Inc., St Louis, MO, USA) to label the microbial community. Leucine is a widely used marker for biomass production in aquatic microbial ecology (Kirchman et al., 1985). It is incorporated into protein, and there is a large set of data from freshwater systems for comparison (Kubitschek, 1968; Jørgensen, 1992; del Giorgio and Cole, 1998). NAG is the subunit of chitin, the main polymer of the daphnia carapace. Thus, bacteria living on a chitinous surface might arguably have the ability to incorporate NAG (Köllner et al., 2012; 
Beier and Bertilsson, 2013). The labelled communities were then distributed to triplicate Erlenmeyer flasks containing four live daphnids (treatment $\mathrm{Rw}$ ) or four anaesthetised daphnids (treatment A), respectively. The third set of labelled microbial communities was filtered onto nitrocellulose membrane filters (type GSWP, $45 \mathrm{~mm}$ diameter, $0.22 \mu \mathrm{m}$ pore size; Millipore) to determine microbial incorporation of the tracer. The filtrate was also collected and added to triplicate Erlenmeyer flasks each containing four daphnids (treatment F).

Live and anaesthetised daphnids were incubated for $1 \mathrm{~h}$ at $20^{\circ} \mathrm{C}$ on a laboratory rocker $(10$ r.p.m. over a tilt angle of $\pm 11^{\circ}$ ). Thereafter, all daphnids were individually picked and anaesthetised in carbon dioxide-rich water. Three individuals from each Erlenmeyer were then transferred to separate scintillation vials with $500 \mu \mathrm{l}$ Soluene350 (Perkin Elmer Inc., San Jose, CA, USA) to solubilise the tissue and incubated at $50{ }^{\circ} \mathrm{C}$ for $\sim 6 \mathrm{~h}$. For one experiment, six $D$. galeata individuals were dissected after labelling and colons and the outer carapaces were separated for uptake measurements. When the daphnids were dissolved, $0.5 \mathrm{ml}$ of scintillation cocktail (Rotiszint eco plus, Carl Roth $\mathrm{GmbH}$, Karlsruhe, Germany) was added and radioactivity was measured in a scintillation counter ( $n=9$ for each treatment and date). The average uptake values of three daphnids from the same Erlenmeyer flask were treated as a single replicate in order to avoid pseudoreplication. One daphnid from each treatment and date was fixed with $\mathrm{EtOH}$, placed on a cover slip and dissected under a binocular microscope for later fluorescence in situ

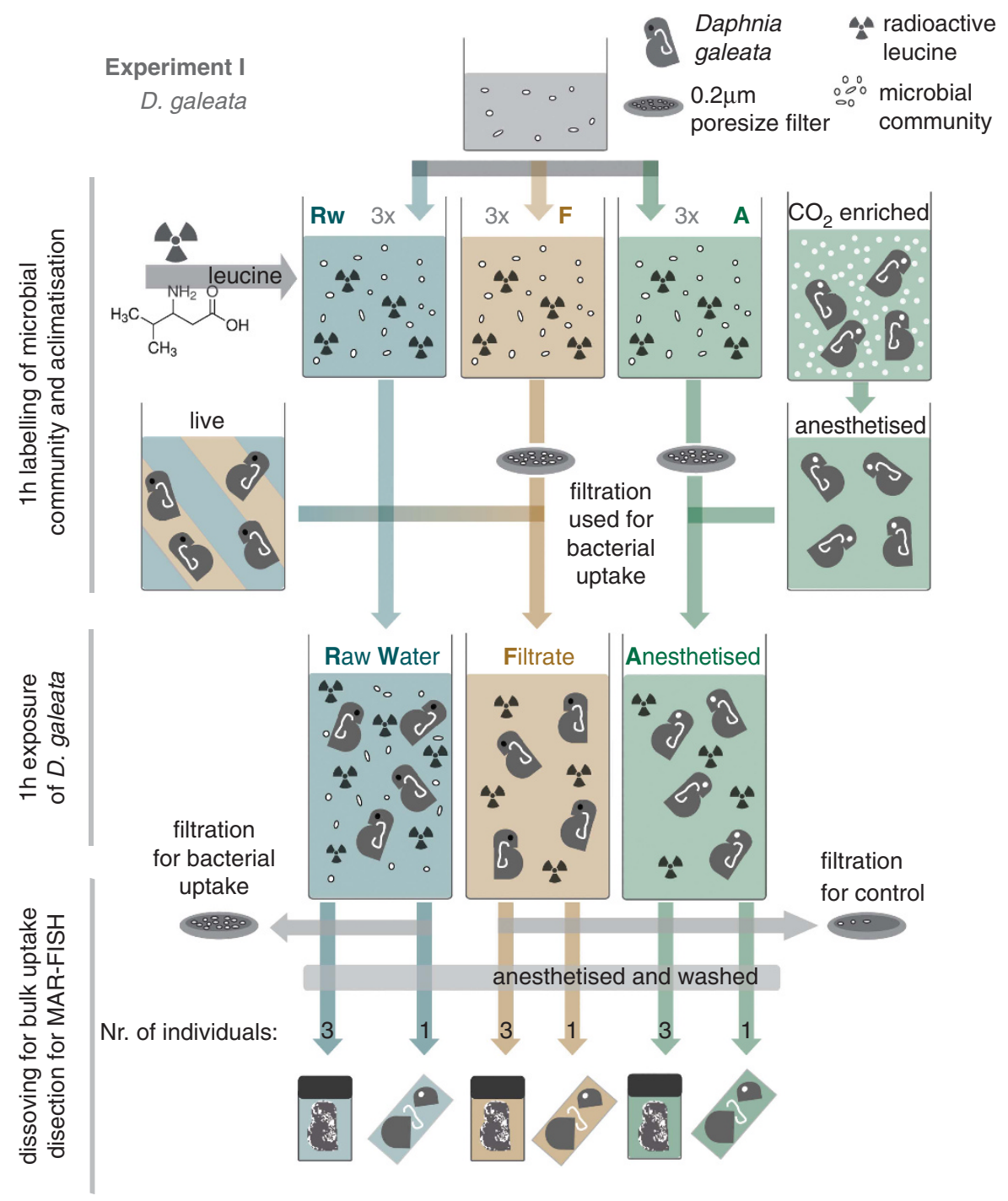

Figure 1 Schematic depiction of the setup of experiment I. For the raw water (Rw) and filtrate (F) treatments, active D. galeata individuals were incubated for $1 \mathrm{~h}$ together with the lake water microbial assemblages (Rw) or in lake water filtrates (F). Both Rw and $\mathrm{F}$ treatments had been preincubated with tritiated leucine for $1 \mathrm{~h}$ before the addition of daphnids. In the anaesthetised treatment (A), daphnids were placed in $\mathrm{CO}_{2}$-enriched mineral water before incubation in the lake water filtrates (negative control). Subsequently, daphnids were either dissected for microautoradiography (MAR-FISH, one animal), or total leucine uptake per individual was determined by scintillation counting (three animals). All treatments were done in triplicates. 
hybridisation (FISH) and microautoradiographyFISH analysis (see below).

Experiment II (Supplementary Figure S1) was essentially performed as described for experiment I, except that daphnids were collected from Lake Zurich, and the microbial communities in the A and $\mathrm{F}$ treatments were removed already before addition of the radioactive tracer to assess the total potential uptake of Daphnia sp. epibionts. Separate triplicate sets of water samples $(10 \mathrm{ml})$ were used to determine tracer uptake by the pelagic bacterial assemblages. Finally, all incubations for experiment II were performed at in situ (lake water) temperatures.

\section{Staining and microscopic analysis}

Dissected daphnids on the cover slips were overlaid with a drop of $0.1 \%$ low melting point agarose and dried at $45^{\circ} \mathrm{C}$. The cover slip was incubated in $90 \%$ $\mathrm{EtOH}$ for $45 \mathrm{~min}$ to fix the bacterial community. FISH and microautoradiography-FISH with probe R-BT065 (Šimek et al., 2001) (targeting bacteria affiliated with Limnohabitans) were essentially conducted as described before (Pernthaler et al., 2002; Alonso and Pernthaler, 2005), although on the cover slips, and predigestion was reduced to a lysozyme treatment of $20 \mathrm{~min}$ only. Microscopic imaging of the filter apparatus was done on an inverse confocal laser scanning microscope (CLSM Leica SP2, Leica Microsystems, Wetzlar, Germany) at the Centre for Microscopy and Image Analysis of the University of Zurich. Images were further processed with the software package Imaris x64 version 7.5.2 (Bitplane AG, Zurich, Switzerland) and arranged using Photoshop CS5 (Adobe Systems Inc., San Jose, CA, USA).

Bacteria were counted on the filter combs of dissected and stained Lake Zurich daphnids from 26 April. Cells on a single filter comb and the corresponding appendages of seven daphnids were quantified and the result was multiplied by four (to account for the number of combs per individual).

\section{Statistical analysis}

Differences between the Rw and A treatments compared with the $\mathrm{F}$ treatment were determined by one-way analysis of variance after natural logarithm transformation of the data to ensure normal distribution, with comparison of the means by Holm-Sidak post hoc test. The analyses were carried out using SigmaPlot 11 (Systat Software, Chicago, IL, USA).

\section{Phylogenetic analysis}

Four 16S rRNA gene clone libraries were constructed to analyse the phylogenetic composition of Limnohabitans bacteria on daphnids from Lake Zurich on cultured D. galeata and in the surrounding media (Lake Zurich water from $5 \mathrm{~m}$ depth and D. galeata cultivation medium). For this purpose, daphnids and water samples from Lake Zurich were obtained on 31 March. All daphnids were washed 3 times in sterile, UV-treated deionised water. DNA was isolated from $\sim 13-16$ daphnids or $250 \mathrm{ml}$ of filtered water using the PowerSoil DNA isolation kit (MO BIO Laboratories, Inc., Carlsbad, CA, USA). The 16S rRNA gene sequences affiliated with Lhb were amplified using the R-Bt065 oligonucleotide (Šimek et al., 2001) as a forward primer (position: 065) and GM4r (position: 1492), a general bacterial reverse primer (Muyzer et al., 1995), resulting in a fragment of $1442 \mathrm{bp}$. PCR conditions were tested with Limnohabitans planktonicus strain II-D5 (Kasalicky et al., 2010), and were optimised in a reaction volume of $25 \mu \mathrm{l}$ GoTaq Green Master Mix (Promega Co., Madison, WI, USA) as follows: $94{ }^{\circ} \mathrm{C}$ for $300 \mathrm{~s}, 94{ }^{\circ} \mathrm{C}$ for $60 \mathrm{~s}, 57^{\circ} \mathrm{C}$ for $30 \mathrm{~s}, 72^{\circ} \mathrm{C}$ for $120 \mathrm{~s}$ (steps 2-4 repeated 30 times) and $72^{\circ} \mathrm{C}$ for $600 \mathrm{~s}$. Three purified PCR products of each sample were pooled and cloned into competent Escherichia coli cells, according to the manufacturer's protocol (pGEM-T Easy Vectors; Promega Co.). Of each transformation, 120 clones were picked and screened for inserts and positive clones were sequenced using the primers listed above plus primer GM1f (position: 518, Muyzer et al., 1993). The sequences were assembled using DNA Baser Sequence Assembler (Heracle BioSoft S.R.L., Pitesti, Romania), aligned with the SINA web aligner (Pruesse et al., 2007) and merged into the SILVA SSU reference database 110 using the software package ARB (Ludwig et al., 2004). Uchime (Edgar et al., 2011) was used to exclude chimeric sequences. Bootstrapped Maximum Likelihood trees (1000 repetitions; Stamatakis et al., 2008) were calculated that comprised the sequences from this study, Limnohabitans sp. isolates as published in Kasalický et al. (2013) and Limnohabitans sequences obtained from $D$. magna gut analysis (Freese and Schink, 2011). The same set of sequences was clustered into operational taxonomic units (OTUs; 99\% identity) using Mothur (Schloss et al., 2009), and the OTU clustering pattern was compared with the results of the phylogenetic analysis. All sequences from this study are deposited in the EMBL database with accession numbers HF96498 - HF968621.

\section{Results and discussion}

Uptake of dissolved leucine by epibionts of D. galeata We labelled a natural microbial community with tritiated leucine, and let D. galeata feed on it for $1 \mathrm{~h}$ (experimental setup: Figure 1). The amount of radiolabel in $D$. galeata because of their incorporation of both dissolved leucine and microbes (raw water treatment (Rw), Figure 1) was compared with the uptake of dissolved leucine only in a treatment where daphnids were placed into the sample after removing the labelled microbial cells by filtration 
(treatment Filtrate (F), Figure 1). The amount incorporated by additionally feeding on microorganisms did not significantly exceed the uptake of substrate from the dissolved fraction only (Figure 2), indicating that leucine-incorporating heterotrophic microbes were of minor importance as a food source for daphnids (Peterson et al., 1978; Nagata and Okamoto, 1988; Martin-Creuzburg et al., 2011). Substantial amounts of radioactivity were detected in daphnids maintained on the filtrate, suggesting uptake of dissolved substrate by the animals (Figure 2): free-living bacteria in $1 \mathrm{ml}$ of water incorporated $0.1 \pm 0.04 \mathrm{pmolh}^{-1}$ leucine, whereas three times higher uptake rates $\left(0.3 \pm 0.04 \mathrm{pmol} \mathrm{h}^{-1}\right)$ were observed per individual daphnid (Figure 2). The level of incorporation of dissolved leucine in this study far exceeds the previously reported uptake of custom labelled algal exudates by daphnids (Speas and Duffy, 1998). This might be ascribed to methodological issues, for example, a low labelling efficiency of the exudates.

To further explore the notion that leucine was readily taken up by epibiotic bacteria, labelled D. galeata individuals were dissected and the separated pieces were overlaid with a photographic emulsion to microscopically localise the deposition of radioactivity on the animal and in bacterial cells by microautoradiography and catalysed reporter deposition FISH (Alonso and Pernthaler, 2005). Strongest labelling was detected around the trunk limbs; particularly on the setae and appendages of trunk limbs 3 and 4 (TL3 and 4, Figure 3). Most uptake on these body surfaces could be assigned to single bacterial cells (Figure 3). The setae and setula of trunk limbs 3 and 4 serve as food-capturing filter sieves (see, for example, Fryer, 1991), and daphnids incessantly filter water through these structures. Besides protecting from protistan grazers and abiotic

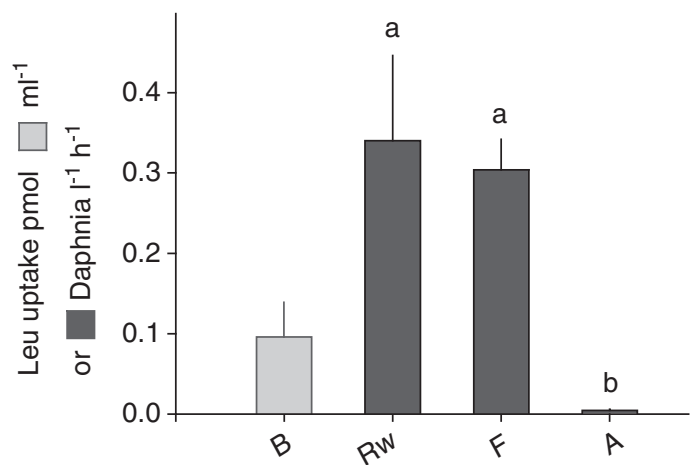

Figure 2 Leucine uptake by the heterotrophic bacterial community (B) after $1 \mathrm{~h}$ of labelling by active $D$. galeata after $1 \mathrm{~h}$ of incubation in the labelled raw water (Rw), and by active $(\mathrm{F})$ and anaesthetised (A) D. galeata maintained for $1 \mathrm{~h}$ in tracer containing $0.2 \mu \mathrm{m}$ prefiltered lake water. Error bars represent the standard errors of triplicate water samples (B) or the standard errors of measurements from three replicates ( $\mathrm{Rw}, \mathrm{F}$ and $\mathrm{A})$. Different lowercase letters above the bars of Rw, F and A indicate significant differences between treatments (analysis of variance (ANOVA), $P<0.5$ ). stressors (Tang et al., 2010, 2011), a steady supply of organic carbon and nutrients may render the filter apparatus an ideal habitat for epibiotic bacteria. This interpretation is further supported by our finding that almost no label was incorporated when daphnids were anaesthetised before being placed in the filtrate (treatment anaesthetised (A), Figure 1). Thus, active filtration by the animals seemed to be a prerequisite for substrate uptake by the epibionts. Furthermore, the proportions of incorporated radioactivity in the external body parts of dissected daphnids were between 4 and $>80$ times higher (mean, 29.5) then in the colons (data not depicted). Epibiotic bacteria have also been described from the feeding appendages of marine copepods, as well as on setae of other crustaceans such as the deep-sea Yeti crab, Kiwa hirsuta (Carman and Dobbs, 1997; Goffredi et al., 2008). It should be noted that $\sim 20 \%$ of the filter combs in 20 analysed daphnids were nearly uncolonised by bacteria. This might be because of moulting processes that have been shown to reduce the parasite loads on daphnids (Duneau and Ebert, 2012), and thus likely also affect the densities of other epibionts and the substrate uptake.

\section{Active epibionts affiliated with Limnohabitans}

Previous studies centred on the identity of Daphniaassociated microbes hint at the importance of Betaproteobacteria, in particular of bacteria related to the genus Limnohabitans (Peter and Sommaruga, 2008; Qi et al., 2009; Freese and Schink, 2011). Therefore, we performed FISH on dissected individuals of $D$. galeata using an oligonucleotide probe for a phylogenetic cluster $(L h b)$ that includes the type strains L. planktonicus and L. parvus (Šimek et al., 2001). A large proportion of the epibionts on the $D$. galeata filter apparatus were affiliated with Lhb (Figure 3), whereas $<0.5 \%$ of cells in the surrounding cultivation water were hybridised with this probe. Most of the epibiotic Lhb bacteria showed visible incorporation of leucine (Figure 3), as detected by microautoradiography-FISH (27). Planktonic Limnohabitans spp. are known to readily incorporate this substrate (Horňák et al., 2006; Salcher et al., 2013). Cultures of L. planktonicus have, moreover, been shown to profit from the presence of algae that has been ascribed to their utilisation of algal exudates (Šimek et al., 2011). In addition to the advantageous supply of such fresh DOC to Limnohabitans spp. on Daphnia filter combs by the filtration activity itself, it is also conceivable that these bacteria might further profit from the products of 'sloppy feeding', that is, organic compounds released by the physical breaking of algal cells (see, for example, Riemann et al., 1986; Carman, 1994).

FISH on segments of various dissected daphnids from Lake Zurich confirmed the presence of epibiotic Lhb bacteria on natural zooplankton populations 

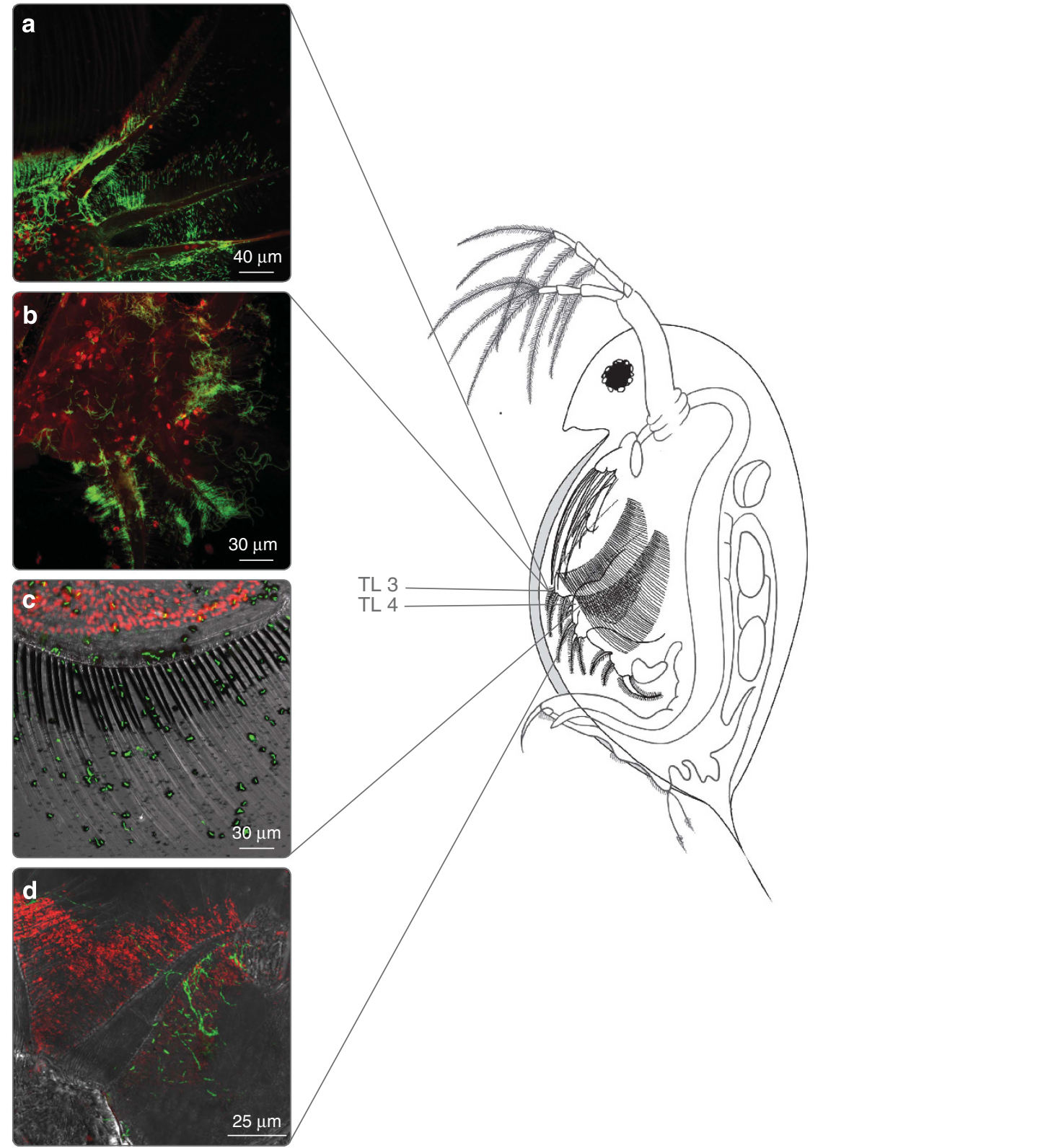

Figure 3 Confocal photomicrographs of Daphnia spp. epibionts (left), and localisation of the depicted structures in a schematic drawing of a daphnid (right). Green cells are hybridised with probe R-Bt065, targeting Lhb bacteria. Depicted in red are other DNA-containing objects, that is, bacterial cells that are not $L h b$ and nuclei of Daphnia. (a, b) D. galeata feeding appendages with hybridised Lhb cells. (c) D. galeata feeding combs with hybridised $L h b$ cells surrounded by black halos from microautoradiography staining that indicates the uptake of tritiated leucine by these bacteria. (d) Feeding appendage of daphnid from Lake Zurich with hybridised Lhb and numerous other bacteria. TL3 and TL4 indicate trunk limbs 3 and 4.

(Figure 3). Although only up to $3 \%$ of the heterotrophic bacteria in lake water were affiliated with Lhb (Figure 5), filter combs of daphnids were typically covered by bacteria from this genus that were, moreover, visibly incorporating leucine. In addition, there were clear morphological differences between planktonic $L h b$ and those associated with daphnids, for example, only the latter formed filamentous morphotypes (Figure 3). Similar to observations in cultures of D. galeata, some filter combs of daphnids in Lake Zurich were also virtually free of bacteria (in 3 out of 17 analysed individuals). In addition, other unidentified bacteria were occasionally found to dominate on the filter seata (Figure 3).

Indications for a core group of epibiotic Limnohabitans sp. To investigate the phylogenetic relationship of Lhb bacteria on daphnids from various sources, we constructed 16S ribosomal DNA clone libraries using the sequence of the $L h b$ probe as a forward primer together with a general bacterial reverse primer. By this we identified bacteria associated 
with D. galeata and Lake Zurich daphnids as well as from the respective surrounding water.

No sequence obtained from the cultivation water of D. galeata was from the genus Limnohabitans. In contrast, $L h b$ sequences were obtained from water samples of Lake Zurich. These sequences were, however, considerably different from the ones retrieved from daphnids (Figure 4). These findings indicate a degree of specificity of the associations between Lhb bacteria and their host (Wahl et al., 2012).

Highest similarity was detected between $L h b$ sequences retrieved from daphnids from Lake Zurich and from the cultured D. galeata (Figure 4). The sequences clustered in two shared OTUs (99\% identity level), as well as forming one specific OTU per source population. One of the shared clusters also included sequences retrieved from the digestive tract of D. magna (Freese and Schink, 2011) and the type strain L. planktonicus (Figure 4; Hahn et al., 2010). It thus seems that there are core phylotypes closely affiliated with $L$. planktonicus that are commonly associated with different species of daphnids from various habitats, as well as a more variable set of other microbiota (Grossart et al., 2009). L. planktonicus was originally isolated from pelagic samples of a freshwater reservoir (Kasalicky et al., 2010). Subsequent analysis, however, revealed, that this species is not common in the pelagic zone of lacustrine waters (Jezbera et al., 2013). It is thus possible that these bacteria in fact predominately inhabit an epibiotic niche. Epibiosis may however not be the exclusive place of occurrence for a particular genotype: the human pathogen Vibrio cholera is present in high abundances in the mouth area of marine copepods, but these bacteria are also found free-living in costal marine waters, although at low densities (Huq et al., 1983;
Unique and shared OTUs
(99\% identity)

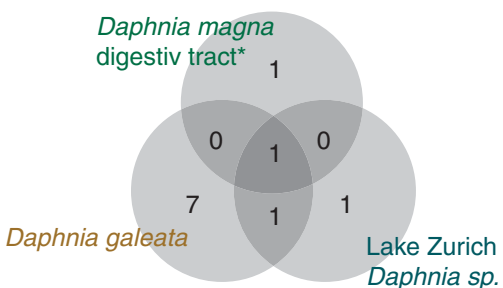

* from Freese et al. (2011)

** from Qi et al. (2009)

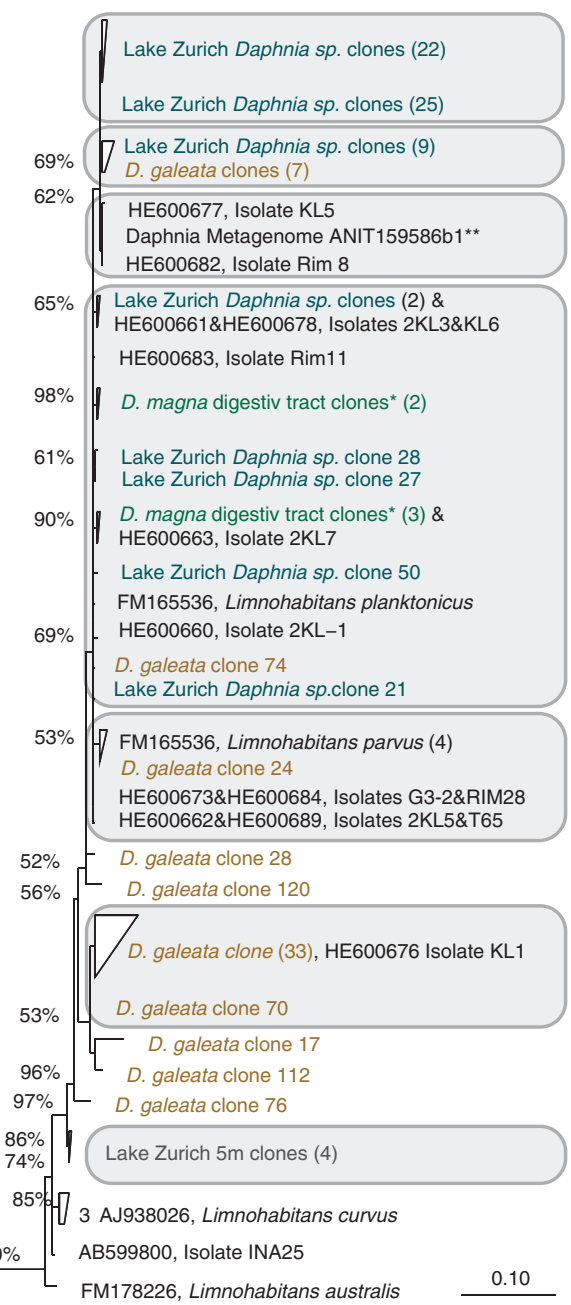

Figure 4 The left panel indicates shared and unique OTUs (99\% identity cutoff) of $16 \mathrm{~S}$ rRNA gene sequences of $L h b$ bacteria from cultured Daphnia galeata, from Lake Zurich daphnids, and from cultured D. magna (Freese et al., 2009). The right panel indicates phylogenetic analysis (Maximum Likelihood method) of Limnohabitans spp. including sequences from cultured strains (Kasalický et al., 2013) and Daphnia metagenome (Qi et al., 2009). The individual OTUs are depicted as grey boxes, the broken line links sets of sequences from a single OTU. Values in brackets refer to the numbers of sequences in 'collapsed' clusters depicted as wedges. Only bootstrap values of $>50 \%$ (1000 replications) are reported. Scale bar, 10\% estimated sequence divergence. 
Heidelberg et al., 2002; Cottingham et al., 2003), Thus, V. cholera may be part of the 'rare biosphere' within pelagic communities while being abundant on zooplankton. A similar occurrence pattern might be hypothesised for bacteria related to L. planktonicus.

Interestingly, closely related $L h b$ sequences were found on the filter combs of D. galeata and in the D. magna digestive tract. A possible explanation lies in the feeding physiology of Daphnia, that is, part of the $L h b$ population on the filter apparatus might be ingested and transported into the digestive system. Freshwater bacteria have been observed to pass the gut of daphnids alive (King et al., 1991). Whether or not Lhb bacteria play a role in the digestion processes within the colon of the animals remains to be explored, as well as the mode of interaction between the Daphnids and Lhb epibionts on the filter combs. It should be emphasised that dead $D$. galeata were never found to be inhabited by $L h b$ bacteria ( $n=6$ inspected individuals), as has already been observed for D. magna (Freese and Schink, 2011). This may indicate that the interaction between $L h b$ bacteria and the animals is not of a pathogenic nature. Moreover, Lhb bacteria might actively leave the surface of Daphnia when the animals moult or die, as has been described for protistan epibionts (Willey and Threlkeld, 1995; Bickel et al., 2012).

\section{Activity of Daphnia epibionts in Lake Zurich:} implication for food webs

In order to assess the in situ relevance of DOC uptake by daphnids (or their epibionts, respectively), we sampled Lake Zurich throughout April and May, starting at the onset of the clear water phase after the spring phytoplankton bloom. Daphnia reached abundances of up to 13 adult and 28 juvenile individuals $\mathrm{l}^{-1}$ (Figure 5), and were dominated by members of the $D$. longispina species complex (D. galeata, cucullata, longispina and hybrids; data: water supply Zurich). The uptake of dissolved leucine by daphnids and by bacterioplankton was determined on four dates (Figures 5 and 6). These experiments were in principle designed as described for the D. galeata cultures, with minor modifications (see Supplementary Figure S1). On three of the four dates, we additionally tested for uptake of NAG (Figure 6), a substrate that is not incorporated by Lhb (Eckert et al., 2012). High uptake rates of both dissolved leucine and NAG were detected, although with large variations between dates (Figure 6). Interestingly, the proportional amount of NAG taken up by the daphnids via consumption of labelled bacteria (normalised to the labelled bacterioplankton community, that is, $(\mathrm{Rw}-\mathrm{F}) / \mathrm{B})$ was consistently higher by approximately fivefold than that of leucine, indicating that Daphnia preferentially fed on NAG- rather than leucineincorporating bacteria. This might be explained by the high NAG uptake rates of large filamentous

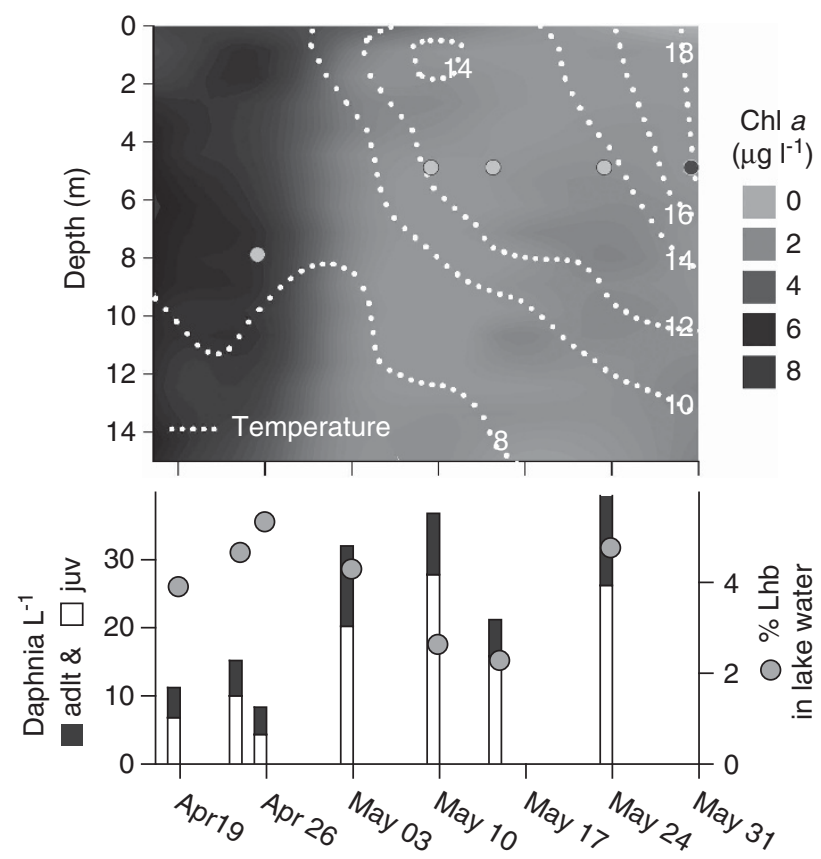

Figure 5 Development of chlorophyll $a$, temperature and of the populations of Daphnia sp. and pelagic Lhb bacteria in Lake Zurich from 17 April to 31 May 2013. Upper panel indicates Chlorophyll $a$ concentrations and temperature between 0 and $15 \mathrm{~m}$ depth. Grey circles indicate the dates and depth of samplings for the incubations with radiolabelled tracers, and for DNA extraction to identify Lhb epibionts (last time point). Lower panel indicates abundances of juvenile (juv) and adult (adlt) daphnids and proportions of pelagic Lhb bacteria of all bacterioplankton cells.

bacteria that are more likely to be grazed by daphnids than, for example, small rod-shaped cells specialised for leucine incorporation (Langenheder and Jürgens, 2001; Pernthaler et al., 2004; Kragelund et al., 2008; Eckert et al., 2013). Alternatively, there might be NAG uptake by some phytoplankton species that are consumed by daphnids (Nedoma et al., 1994). Thus, the transfer mode of DOC to daphnids may in fact differ for individual organic compounds: Although the direct incorporation of heterotrophic bacteria seemed unimportant for leucine uptake of zooplankton, their foraging on NAG-labelled microbes was of greater relevance.

The observed uptake of both NAG and leucine by daphnids incubated in bacteria-free filtrates is evidence for a high, temporarily variable DOC incorporation in situ, likely mediated via the attached bacterial flora. This is suggested by the high proportion of tracer incorporation on the external body surfaces as compared with the digestive tract (data not depicted). Each daphnid approximately hosted $10^{5}$ bacteria on their filter combs, as estimated from counts on individuals from 26 April. Assuming that $50-60 \%$ of the tracer is incorporated on these surfaces (as concluded from our laboratory experiment, data not depicted), the per-cell activity of bacteria on the filter combs is more than two orders of magnitude higher than of 
1816
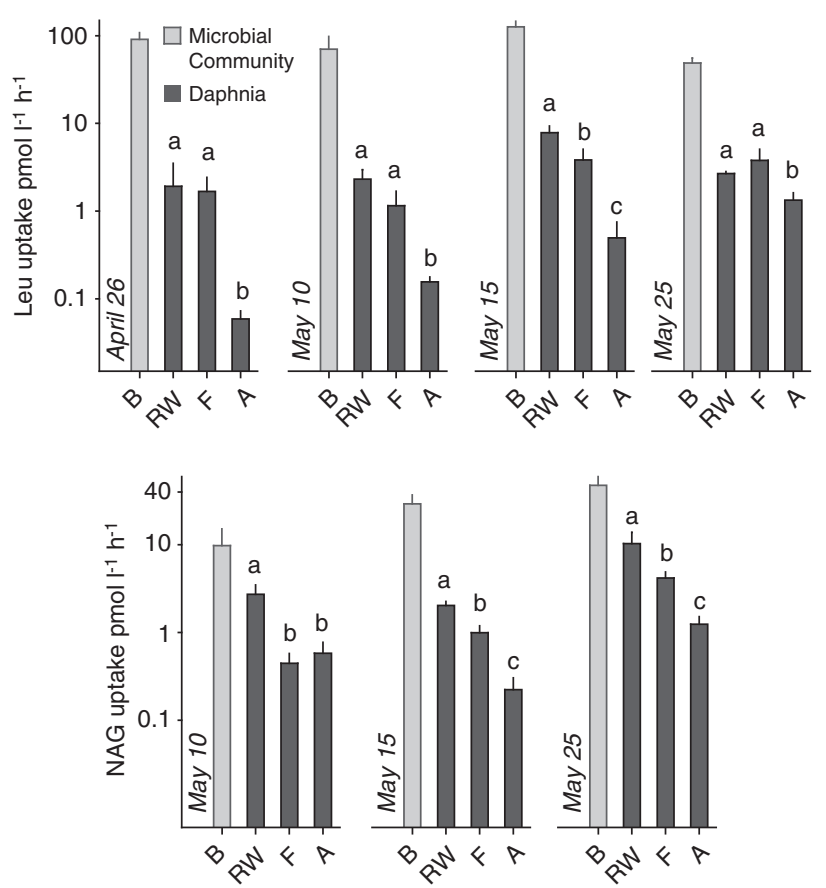

Figure 6 Uptake of tritiated leucine (upper panels) and NAG (lower panels) by the heterotrophic bacterial community (B) after $1 \mathrm{~h}$ of incubation, by lake daphnids after $1 \mathrm{~h}$ of incubation in this labelled raw water (Rw), and by active $(\mathrm{F})$ and anaesthetised lake daphnids (A) maintained for $1 \mathrm{~h}$ in tracer containing $0.2 \mu \mathrm{m}$ prefiltered lake water. The experimental dates are indicated in each panel. Error bars represent the standard errors of triplicate water samples (B) or the standard errors of measurements from three replicates ( $\mathrm{Rw}, \mathrm{F}$ and A). Different lowercase letters on the bars of Rw, F and A indicate significant differences between the treatments $(P<0.5)$.

free-living lake bacteria. This is in agreement with findings from marine systems that zooplanktonassociated bacteria are metabolically more active than free-living bacteria (Møller et al., 2007). Moreover, attached bacteria move through the water column with the host (Grossart et al., 2010). Daphnids tend to search for patches with higher food concentration (Larsson and Kleiven, 1996; Dodson et al., 1997) and might thereby give an additional advantage to attached bacteria, that is, by transporting them to hot spots of organic carbon and inorganic nutrients (Grossart et al., 2010).

If extrapolated to the total daphnid population in lake water, the incorporation amounted to up to $8 \%$ of the leucine and nearly $9 \%$ of the NAG uptake by the bacterioplankton. Although this proportion may seem small at a first glance, such direct transfer of low-molecular-weight DOC to zooplankton may nevertheless be of considerable importance. The positive effect of Daphnia on the size of fish populations in lakes is mainly attributed to the fact that Daphnia feed on primary producers and are in turn consumed by fish that is, the cascade algaedaphnia-fish is considered to be highly efficient because of its shortness (Stockner and Porter, 1988; Stockner and Shortreed, 1989). Similarly, the prokaryotic epibionts on daphnids may form a more direct link between microbial DOC uptake and fish predation. Such a shortcut would circumvent the passage of substrates through intermediate levels of the microbial food web, thereby avoiding the significant respiration losses associated with these trophic transitions (Lindeman, 1942; Pomeroy and Wiebe, 1988; Stockner and Shortreed, 1989). This may be illustrated by a highly simplified lake food web consisting of planktivorous fish, Daphnia, phytoplankton, protists, bacteria and DOC. In this food web, fish feed on Daphnia that feed on protists and phytoplankton. The latter provides DOC for bacteria that are in turn incorporated by protists. However, the pathway of the transfer of organic carbon changes when epibiosis is included: if fish feed on Daphnia, they also ingest the attached bacteria. Thus, fish concomitantly consume organisms that are considered to belong to different trophic levels, and all of these organisms will contribute to their biomass. Considering the 'Rule of 10 ' concept (stating that only $10 \%$ of energy is transferred from a given trophic level to the next one; Lindeman, 1942), at least $0.1 \%$ of the total microbial DOC (leucine) uptake would be transferred to fish via the epibiotic bacteria. In comparison, $<0.01 \%$ of DOC would reach fish through the 'classical' microbial loop because of the losses that occur across two or more intermediate trophic levels (that is, protists, daphnids). Thus, 10 times more carbon would be transferred to fish from epibiotic bacteria than from free-living bacteria. This suggests that zooplankton epibionts such as Limnohabitans sp. might play a disproportionally important role for the transfer of DOC from both autochthonous and terrestrial sources to the top trophic levels in lacustrine ecosystems.

\section{Acknowledgements}

We are particularly indebted to Piet Spaaks, Marina Manca and Esther Keller for providing us with Daphnia galeata and the introduction to Daphnia handling, and to Julia Huber for Daphnia artwork. Michaela Salcher is acknowledged for providing DNA from Lake Zurich, Jörg Villiger for bioinformatic assistance, Eugen Loher for help with sampling and Thomas Posch for comments on data analysis and the manuscript. We also thank Karel Šimek and Voijta Kasalický for interesting discussions about Limnohabitans. The assistance and support of the Centre for Microscopy and Image Analysis at the University of Zurich is acknowledged. This study was funded by the Swiss National Science Foundation (Project 31EE30-132771) as part of the European Collaborative Research Program (EUROCORES) Ecological and Evolutionary Functional Genomics (EuroEEFG) of the European Science Foundation.

\section{References}

Alonso C, Pernthaler J. (2005). Incorporation of glucose under anoxic conditions by bacterioplankton from 
coastal North Sea surface waters. Appl Environ Microbiol 71: 1709-1716.

Bascompte J. (2010). Structure and dynamics of ecological networks. Science 329: 765-766.

Beier S, Bertilsson S. (2013). Bacterial chitin degradationmechanisms and ecophysiological strategies. Front Microbiol 4: 149.

Bickel SL, Tang KW, Grossart H-P. (2012). Ciliate epibionts associated with crustacean zooplankton in German lakes: Distribution, motility and bacterivory. Front Microbiol 3: 243.

Brett MT, Kainz MJ, Taipale SJ, Seshan H. (2009). Phytoplankton, not allochthonous carbon, sustains herbivorous zooplankton production. Proc Natl Acad Sci USA 106: 21197-21201.

Carman KR. (1994). Stimulation of marine free-living and epibiotic bacterial activity by copepod excretions. FEMS Microbiol Ecol 14: 255-261.

Carman KR, Dobbs FC. (1997). Epibiotic microorganisms on copepods and other marine crustaceans. Microsc Res Tech 37: 116-135.

Cole JJ, Carpenter SR, Pace ML, Van de Bogert MC, Kitchell JL, Hodgson JR. (2006). Differential support of lake food webs by three types of terrestrial organic carbon. Ecol Lett 9: 558-568.

Corno G, Villiger J, Pernthaler J. (2012). Coaggregation in a microbial predator-prey system affects competition and trophic transfer efficiency. Ecology 94: 870-881.

Cottingham KL, Chiavelli DA, Taylor RK. (2003). Environmental microbe and human pathogen: the ecology and microbiology of Vibrio cholerae. Front Ecol Environ 1: 80-86.

del Giorgio PA, Cole JJ. (1998). Bacterial growth efficiency in natural aquatic systems. Annu Rev Ecol Syst 29: $503-541$

Dodson SI, Ryan S, Tollrian R, Lampert W. (1997). Individual swimming behavior of Daphnia: effects of food, light and container size in four clones. J Plankton Res 19: 1537-1552.

Duneau D, Ebert D. (2012). The role of moulting in parasite defence. Proc $R$ Soc B Biol Sci 279: 3049-3054.

Ebert D. (2008). Host-parasite coevolution: insights from the Daphnia-parasite model system. Curr Opin Microbiol 11: 290-301.

Eckert EM, Salcher MM, Posch T, Eugster B, Pernthaler J. (2012). Rapid successions affect microbial N-acetylglucosamine uptake patterns during a lacustrine spring phytoplankton bloom. Environ Microbiol 14: 794-806.

Eckert EM, Baumgartner M, Huber IM, Pernthaler J. (2013). Grazing resistant freshwater bacteria profit from chitin and cell-wall-derived organic carbon. Environ Microbiol 15: 2019-2030.

Edgar RC, Haas BJ, Clemente JC, Quince C, Knight R. (2011). UCHIME improves sensitivity and speed of chimera detection. Bioinformatics 27: 2194-2200.

Freese H, Eggert A, Garland J, Schumann R. (2009). Substrate utilization profiles of bacterial strains in plankton from the River Warnow, a humic and eutrophic river in North Germany. Microb Ecol 59: 59-75.

Freese H, Schink B. (2011). Composition and stability of the microbial community inside the digestive tract of the aquatic crustacean Daphnia magna. Microb Ecol 62: 882-894.

Fryer G. (1991). Functional morphology and the adaptive radiation of the Daphniidae (Branchiopoda: Anomopoda). Phil Trans $R$ Soc Lond B 331: 1-99.
Goffredi SK, Jones WJ, Erhlich H, Springer A, Vrijenhoek RC. (2008). Epibiotic bacteria associated with the recently discovered Yeti crab, Kiwa hirsuta. Environ Microbiol 10: 2623-2634.

Grey J, Jones RI, Sleep D. (2001). Seasonal changes in the importance of the source of organic matter to the diet of zooplankton in Loch Ness, as indicated by stable isotope analysis. Limnol Oceanogr 46: 505-513.

Grossart HP, Dziallas C, Tang KW. (2009). Bacterial diversity associated with freshwater zooplankton. Environ Microbiol Rep 1: 50-55.

Grossart HP, Dziallas C, Leunert F, Tang KW. (2010). Bacteria dispersal by hitchhiking on zooplankton. Proc Natl Acad Sci USA 107: 11959-11964.

Hahn MW, Kasalický V, Jezbera J, Brandt U, Jezberova J, Šimek K. (2010). Limnohabitans curvus gen. nov., sp nov., a planktonic bacterium isolated from a freshwater lake. Int J Syst Evol Microbiol 60: 1358-1365.

Heidelberg JF, Heidelberg KB, Colwell RR. (2002). Seasonality of Chesapeake Bay bacterioplankton species. Appl Environ Microbiol 68: 5488-5497.

Horňák K, Jezbera J, Nedoma J, Gasol JM, Šimek K. (2006). Effects of resource availability and bacterivory on leucine incorporation in different groups of freshwater bacterioplankton, assessed using microautoradiography. Aquat Microb Ecol 45: 277-289.

Huq A, Small EB, West PA, Huq MI, Rahman R, Colwell RR. (1983). Ecological relationships between Vibrio cholerae and planktonic crustacean copepods. Appl Environ Microbiol 45: 275-283.

Jezbera J, Jezberová J, Kasalický V, Simek K, Hahn MW. (2013). Patterns of Limnohabitans microdiversity across a large set of freshwater habitats as revealed by reverse line blot hybridization. PLoS One 8: e58527.

Jørgensen NOG. (1992). Incorporation of [3H] leucine and $[3 \mathrm{H}]$ valine into protein of freshwater bacteria: uptake kinetics and intracellular isotope dilution. Appl Environ Microbiol 58: 3638-3646.

Kasalicky V, Jezbera J, Simek K, Hahn MW. (2010). Limnohabitans planktonicus sp. nov. and Limnohabitans parvus sp. nov., planktonic betaproteobacteria isolated from a freshwater reservoir, and emended description of the genus Limnohabitans. Int J Syst Evol Microbiol 60: $2710-2714$.

Kasalický V, Jezbera J, Hahn MW, Šimek K. (2013). The diversity of the Limnohabitans genus, an important group of freshwater bacterioplankton, by characterization of 35 isolated strains. PLoS One 8: e58209.

Kerb H. (1911). Über den Nährwert der im Wasser gelösten Stoffe. Int Rev Gesamten Hydrobiol Hydrograph 3: 496-505.

King CH, Sanders RW, Shotts EB, Porter KG. (1991). Differential survival of bacteria ingested by zooplankton from a stratified eutrophic lake. Limnol Oceanogr 36: 829-845.

Kirchman D, Knees E, Hodson R. (1985). Leucine incorporation and its potenial as a measure of protein-sythesis by bacteria in natural aquatic systems. Appl Environ Microbiol 49: 599-607.

Köllner KE, Carstens D, Keller E, Vazquez F, Schubert CJ, Zeyer J et al. (2012). Bacterial Chitin hydrolysis in two lakes with contrasting trophic statuses. Appl Environ Microbiol 78: 695-704.

Kragelund C, Levantesi C, Borger A, Thelen K, Eikelboom D, Tandoi $\mathrm{V}$ et al. (2008). Identity, abundance and ecophysiology of filamentous bacteria belonging to 
the Bacteroidetes present in activated sludge plants. Microbiology-(UK) 154: 886-894.

Krogh A. (1930). Über die Bedeutung von gelösten organischen Substanzen bei der Ernährung von Wassertieren. Z Vgl Physiol 12: 668-681.

Kubitschek H. (1968). Constancy of uptake during the cell cycle in Escherichia coli. Biophys J 8: 1401-1412.

Kuwae T, Miyoshi E, Hosokawa S, Ichimi K, Hosoya J, Amano T et al. (2012). Variable and complex food web structures revealed by exploring missing trophic links between birds and biofilm. Ecol Lett 15: 347-356.

Langenheder S, Jürgens K. (2001). Regulation of bacterial biomass and community structure by metazoan and protozoan predation. Limnol Oceanogr 46: 121-134.

Larsson P, Kleiven OT. (1996). Food search and swimming speed in Daphnia. In: Lenz PH, Hartline DK, Purcell JE, Macmillan DL (eds). Zoooplankton: Sensory Ecology and Physiology. Gordon \& Breach: Amsterdam, The Netherlands, pp 375-387.

Lindeman RL. (1942). The trophic-dynamic aspect of ecology. Ecology 23: 399-418.

Ludwig W, Strunk O, Westram R, Richter L, Meier H, Yadhukumar et al. (2004). ARB: a software environment for sequence data. Nucleic Acids Res 32: 1363-1371.

Martin-Creuzburg D, Beck B, Freese HM. (2011). Food quality of heterotrophic bacteria for Daphnia magna: evidence for a limitation by sterols. FEMS Microbiol Ecol 76: 592-601.

Miner BE, De Meester L, Pfrender ME, Lampert W, Hairston NG. (2012). Linking genes to communities and ecosystems: Daphnia as an ecogenomic model. Proc $R$ Soc B Biol Sci 279: 1873-1882.

Møller EF, Riemann L, Søndergaard M. (2007). Bacteria associated with copepods: abundance, activity and community composition. Aquat Microb Ecol 47: 99-106.

Mougi A, Kondoh M. (2012). Diversity of interaction types and ecological community stability. Science 337: 349-351.

Muyzer G, De Waal EC, Uitterlinden AG. (1993). Profiling of complex microbial populations by denaturing gradient gel electrophoresis analysis of polymerase chain reaction-amplified genes coding for $16 \mathrm{~S}$ rRNA. Appl Environ Microbiol 59: 695-700.

Muyzer G, Teske A, Wirsen CO, Jannasch HW. (1995). Phylogenetic relationships of Thiomicrospira species and their identification in deep-sea hydrothermal vent samples by denaturing gradient gel electrophoresis of 16S rDNA fragments. Arch Microbiol 164: 165-172.

Nagata T, Okamoto K. (1988). Filtering rates on natural bacteria by Daphnia longispina and Eodiaptomus japonicus in Lake Biwa. J Plankton Res 10: 835-850.

Nedoma J, Vrba J, Hejzlar J, Šimek K, Straskrabová V. (1994). N-acetylglucosamine dynamics in fresh-water environments - concentration of amino-sugars, extracellular enzyme-activities, and microbial uptake. Limnol Oceanogr 39: 1088-1100.

Newton RJ, Jones SE, Eiler A, McMahon KD, Bertilsson S. (2011). A guide to the natural history of freshwater lake bacteria. Microbiol Mol Biol Rev 75: 14-49.

Pace ML, Cole JJ, Carpenter SR, Kitchell JF, Hodgson JR, Van de Bogert MC et al. (2004). Whole-lake carbon-13 additions reveal terrestrial support of aquatic food webs. Nature 427: 240-243.

Pernthaler A, Pernthaler J, Amann R. (2002). Fluorescence in situ hybridization and catalyzed reporter deposition for the identification of marine bacteria. Appl Environ Microbiol 68: 3094-3101.
Pernthaler J, Zöllner E, Warnecke F, Jürgens K. (2004). Bloom of filamentous bacteria in a mesotrophic lake: identity and potential controlling mechanism. Appl Environ Microbiol 70: 6272-6281.

Peter H, Sommaruga R. (2008). An evaluation of methods to study the gut bacterial community composition of freshwater zooplankton. J Plankton Res 30: 997-1006.

Peterson BJ, Hobbie JE, Haney JF. (1978). Daphnia grazing on natural bacterial. Limnol Oceanogr 23: 1039-1044.

Pomeroy L, Wiebe W. (1988). Energetics of microbial food webs. Hydrobiologia 159: 7-18.

Pruesse E, Quast C, Knittel K, Fuchs BM, Ludwig WG, Peplies J et al. (2007). SILVA: a comprehensive online resource for quality checked and aligned ribosomal RNA sequence data compatible with ARB. Nucleic Acids Res 35: 7188-7196.

Qi WH, Nong G, Preston JF, Ben-Ami F, Ebert D. (2009). Comparative metagenomics of Daphnia symbionts. BMC Genomics 10: 1471-2164.

Riemann B, Jørgensen NOG, Lampert W, Fuhrman JA. (1986). Zooplankton induced changes in dissolved free amino acids and in production rates of freshwater bacteria. Microb Ecol 12: 247-258.

Salcher MM, Posch T, Pernthaler J. (2013). In situ substrate preferences of abundant bacterioplankton populations in a prealpine freshwater lake. Isme J 7: 896-907.

Schloss PD, Westcott SL, Ryabin T, Hall JR, Hartmann M, Hollister EB et al. (2009). Introducing mothur: opensource, platform-independent, community-supported software for describing and comparing microbial communities. Appl Environ Microbiol 75: 7537-7541.

Šimek K, Pernthaler J, Weinbauer MG, Horňák K, Dolan JR, Nedoma J et al. (2001). Changes in bacterial community composition and dynamics and viral mortality rates associated with enhanced flagellate grazing in a mesoeutrophic reservoir. Appl Environ Microbiol 67: 2723-2733.

Šimek K, Horňák K, Jezbera J, Mašin M, Nedoma J, Gasol JM et al. (2005). Influence of top-down and bottom-up manipulations on the R-BT065 subcluster of betaproteobacteria, an abundant group in bacterioplankton of a freshwater reservoir. Appl Environ Microbiol 71: 2381-2390.

Šimek K, Kasalický V, Zapomelova E, Horňák K. (2011). Alga-derived substrates select for distinct Betaproteobacterial lineages and contribute to niche separation in Limnohabitans strains. Appl Environ Microbiol 77: 7307-7315.

Speas DW, Duffy WG. (1998). Uptake of dissolved organic carbon (DOC) by Daphnia pulex. J Freshw Ecol 13: 457-463.

Stamatakis A, Hoover P, Rougemont J. (2008). A rapid bootstrap algorithm for the RAxML web servers. Syst Biol 57: 758-771.

Stockner J, Porter K. (1988). Microbial food webs in freshwater planktonic ecosystems. In: Carpenter SR (ed) Complex Interactions in Lake Communities. Springer: New York, pp 69-83.

Stockner JG, Shortreed KS. (1989). Algal picoplankton production and contribution to food-webs in oligotrophic British Columbia lakes. Hydrobiologia 173: 151-166.

Taipale S, Kankaala P, Tiirola M, Jones RI. (2008). Wholelake dissolved inorganic (13)C additions reveal seasonal shifts in zooplankton diet. Ecology 89: 463-474.

Tang KW, Turk V, Grossart HP. (2010). Linkage between crustacean zooplankton and aquatic bacteria. Aquat Microb Ecol 61: 261-277. 
Tang KW, Dziallas C, Grossart HP. (2011). Zooplankton and aggregates as refuge for aquatic bacteria: protection from UV, heat and ozone stresses used for water treatment. Environ Microbiol 13: 378-390.

Thébault E, Fontaine C. (2010). Stability of ecological communities and the architecture of mutualistic and trophic networks. Science 329: 853-856.
Wahl M, Goecke F, Labes A, Dobretsov S, Weinberger F. (2012). The second skin: ecological role of epibiotic biofilms on marine organisms. Front Microbiol 3: 1-21.

Willey RL, Threlkeld ST. (1995). Changes in epibiotic burden during the intermolt of Daphnia determined by hypodermal retraction stages. Hydrobiologia 307: 213-219.

Supplementary Information accompanies this paper on The ISME Journal website (http://www.nature.com/ismej) 